\title{
O narrar com as imagens pelas crianças: modos de convívio com histórias na contemporaneidade
}

\author{
Narrating through children's images: ways of living
}

with stories in contemporary times

Adriana Hoffmann Fernandes*

Universidade Federal do Estado do Rio de Janeiro

Resumo $O$ artigo traz resultados da pesquisa de Doutorado em que se buscou investigar os modos de relação das crianças com as narrativas no contexto atual. $\mathrm{O}$ estudo foi fundamentado nos Estudos Culturais Latino-Americanos que entendem o "cultural" na perspectiva da hibridação (CANCLINI, 2003). A investigação ocorreu em três escolas, um espaço cultural e um blog. O estudo foi desenvolvido por intermédio de uma pesquisa qualitativa de cunho etnográfico através de oficinas e entrevistas realizadas com as crianças participantes e as crianças produtoras de um blog. Os achados da pesquisa mostram a frequente relação das crianças com a imagem, mostrando o quanto a leitura das crianças é híbrida, misturando as diferentes linguagens na integração das linguagens oral, escrita e visual na formação das crianças como leitores.

PALAVRAS-CHAVE: Criança, Narrativa, Formação do leitor, Imagem.

Abstract The article brings the results of a Doctoral research which aimed at investigating the children's relation with narratives in contemporary times. The study was based on the Latin-American Cultural Studies that recognize "cultural" in the hybrid perspective (CANCLINI, 2003). The investigation was carried out in three schools, a cultural center and a blog. The study was developed through a qualitative research with an ethnographic approach by developing workshops and interviewing the participant children and the children who produced a blog. The findings of the research show the recurrent relation of children with images, what revealed how children's reading is hybrid and mixes different languages integrating oral, written and visual languages in their formation as readers.

KEYWORDS: Child, Reader's development process, Narrative, Image. 


\section{Introdução}

A presença cada vez maior de estudos reiterando as mudanças e as características da infância atual trazem uma questão: não seria fundamental entender melhor o contexto de convívio das crianças com as narrativas? Como vem sendo discutido por vários autores (ÁRIES, 1983; PERROTTI, 1990) o conceito de infância é cultural, muda de acordo com o contexto e a época histórica em que vivemos. Então, o que significa ser criança na sociedade contemporânea? O que significa viver sua infância em meio aos diferentes modos de contar trazidos pelas histórias que são exibidas na TV, nos livros, no cinema, nas revistas, entre outras formas de acesso às histórias? Como as crianças convivem com essa multiplicidade de histórias que circulam em seu cotidiano e que escolhas fazem a partir desse convívio?

Usaremos aqui a análise que Eric Hobsbawn (1995) traça da "revolução cultural" que marcou a segunda metade do século XX pois esta é fundamental para refletir sobre as transformações culturais que vêm acontecendo nas formas como a criança se relaciona contemporaneamente com o conhecimento e com a cultura.

O estudo que apresento traz parte dos resultados da minha Tese de Doutorado (2009) e justifica-se pela importância de compreender o contexto da criança na atualidade, este cada vez mais fluido, mutável e que precisa ser sempre olhado com cuidado por aqueles que se preocupam com a formação das novas gerações. Como Benjamin (1985), que ajuda a discernir que as novas formas de percepção se expressam num sensorium diferente em razão da técnica, das novas tecnologias, é preciso pensar que a relação cada vez maior das crianças com as produções narrativas da atualidade pode também modificar seus modos de produção cultural.

Se hoje a criança entra em contato desde cedo com diferentes narrativas que se expressam tanto nos livros como nos meios de comunicação, faz sentido supor que se modifica também seu modo de contar perante esse contexto de múltiplas "alfabetizações". Retomando a noção de que as narrativas são a expressão do que se vive na cultura e expressam - de algum modo - a experiência que temos com essa cultura, me pergunto, em relação às crianças, que histórias estão sendo contadas por elas que expressam, de alguma forma, sua experiência de infância no mundo atual? Entendo a narrativa pelas diferentes formas dessas contarem histórias descrevendo também um pouco de como se constituem como crianças nesse contexto.

A concepção de infância que me guiou nesse estudo implicou entender as crianças que dele participaram como coautoras, sujeitos que negociam, compartilham e criam culturas. No momento atual, em que a revolução tecnológica vem ocasionando mudanças nas maneiras das pessoas se relacionarem cotidianamente com o conhecimento e a cultura, causando perplexidade e insegurança nas gerações mais velhas, é quase um imperativo desenvolver pesquisas com crianças e não sobre crianças. ${ }^{1}$ 


\section{Referenciais teórico-metodológicos da pesquisa}

Canclini, estudioso dos Estudos Culturais, dialoga com essa perspectiva ao enfocar a cultura na ótica da interculturalidade, entendendo-a como um processo de mudança e não como um "pacote de características fixas". Por esse motivo o autor opta por nomeá-la pelo adjetivo, tal como discute Appadurai (apud Canclini, 2005), já que o adjetivo traz de forma mais abrangente esse sistema de relações de sentido que identificam "diferenças, contrastes e comparações" que compõem "o cultural". Ao propor estudar o cultural, o autor abarca um conjunto de processos através dos quais dois ou mais grupos representam e intuem imaginariamente o social, concebem e geram as relações com os outros. O cultural da infância existe nos espaços em que a infância se constitui, fazendo relações e criando sentidos que são produzidos nos coletivos. $\mathrm{O}$ autor revela a transformação cultural que foi se configurando no decorrer do século XX, nos fazendo pensar nos modos como ela ocorre, designando por "hibridação" os processos socioculturais nos quais estruturas ou práticas discretas, que antes existiam de forma separada, se combinam para gerar novas estruturas, objetos e práticas. A apropriação dos sujeitos gera novas práticas diferentes das que lhes deram origem. Tal processo surge da criatividade individual e coletiva nas artes, na vida cotidiana e no desenvolvimento tecnológico. Nesse sentido, os meios de comunicação são entendidos, então, como veículos de hibridação. Assim, quanto mais meios e tecnologias a sociedade dispõe mais complexificam-se os processos de comunicação e os processos culturais e sociais. Isso explica porque hoje já não se justifica mais, do ponto de vista dos Estudos Culturais Latino-Americanos, estudar a mídia pura e simplesmente, ou seja, os meios de comunicação e suas mensagens em si, deslocadas dos grupos sociais e dos processos culturais que a elas dão sentido. Nessa perspectiva, como aponta Martin-Barbero, o problema de fundo agora não está mais nas mídias, mas nos mediadores e nos modelos culturais que influenciam os sentidos que são produzidos sobre elas.

Coerentemente com tal abordagem teórico-metodológica dos Estudos Culturais, o trabalho aqui apresentado foi desenvolvido por intermédio de uma pesquisa qualitativa de cunho etnográfico através de oficinas de troca e produção de narrativas em escolas e centro cultural com crianças. As oficinas são espaços de produção cultural que geram narrativas e práticas criadas pelas crianças na produção coletiva. As oficinas da pesquisa foram propostas em ambientes diferentes - num espaço cultural e em escolas (uma pública e uma particular) para que fosse possível perceber, de forma mais ampla, a relação das crianças de 7 a 11 anos com as narrativas em diferentes contextos. Assim como as oficinas e o blog seriam entendidos como espaço de constantes produções que se ampliam na troca entre pares gerada nos momentos coletivos. Por esse motivo a investigação não tem como objetivo comparar faixas etárias mas perceber, independente dessas faixas, quais são os diferentes modos de apropriação criados pelas crianças a partir das histórias, percebendo de que forma produzem sentidos e apropriam-se das histórias a que têm acesso, criando novas possibilidades de narrar com e a partir delas nesses diferentes contextos. As oficinas aconteceram durante 8 encontros 
semanais (cerca de 2 meses em cada campo), tempo em que também houve a observação e coleta das produções do blog para posteriores conversas na ótica de entrevistas coletivas com as crianças sobre as observações e produções coletadas.

Articulando infância, mídia e educação privilegio o trabalho com as crianças e escolho, dessa forma, pesquisar as suas narrativas como um modo de perceber essas interações e criações nas apropriações feitas por elas das produções culturais da atualidade, sejam elas orais, audiovisuais (cinema, TV, vídeo), escritas, etc. Desse modo, o objetivo também era perceber tais apropriações feitas por elas, independente da idade que tivessem, e por isso não foram feitos julgamentos de valor sobre tais apropriações como melhores ou piores.

A oficina promove um clima alegre e descontraído e constitui-se não só como uma perspectiva ética da pesquisa com crianças como promove que elas, na interação umas com as outras, conversem entre si, diminuindo as dessimetrias entre pesquisador e sujeitos, ainda mais quando esses sujeitos são crianças. Esse clima também propicia que a pesquisadora se envolva no processo de pesquisa de forma mais descontraída, o que favorece não só sua relação com as crianças, mas também permite que possa desenvolver atividades que interessem de fato elas, instigando sua participação.

As oficinas aconteceram da seguinte maneira nos campos da pesquisa: 8 encontros semanais com uma média de 15 crianças participantes. Nesses encontros, as crianças vivenciaram várias propostas de ouvir, ver e contar histórias em seus diferentes suportes. A variação ocorrida de um grupo para outro deu-se pela própria experiência das crianças de cada escola ao trazerem sugestões e histórias que eram incorporadas às oficinas realizadas, já que fazíamos a pesquisa com elas e o que era trazido por elas modificava assim o próprio campo de pesquisa. Em todas as oficinas tivemos momentos iniciais em que propusemos às crianças que trouxessem e contassem histórias preferidas suas dizendo de onde as conheciam se livro, filme, TV, por alguém ter contado, etc e, a partir disso, faziamos a criação recriação das suas narrativas conhecidas. As recriações podiam ser feitas de acordo com a escolha das crianças, em forma de: escrita, desenhos, teatro, narrativa oral, etc.

Já o blog pesquisado foi o bloguinho do $O$ Globo, ${ }^{2}$ produzido a cada 6 meses por um grupo de crianças de mesma faixa etária dos campos anteriores selecionadas por um concurso de redação. $\mathrm{O}$ blog entrou como um quarto campo de pesquisa ao percebermos que, nos campos anteriores, havia a impossibilidade de expressão de narrativas via computador, já que nas escolas e no espaço cultural o computador não era acessível às crianças. No blog fizemos a coleta das produções das narrativas das crianças, analisamos e depois entrevistamos as crianças participantes para perceber como pensavam a respeito do seu processo de produção narrativa nesse contexto. Dos participantes do blog (cerca de 25 crianças), eu analisei as produções postadas e entrei em contato com todas as crianças participantes, buscando contato para entrevista/autorização dos pais. Dessas, apenas 6 deram retorno e fizeram parte das análises finais do estudo nesse quarto campo de pesquisa. 
O artigo aqui apresentado reflete, portanto, sobre os sentidos construídos pelas crianças nos diferentes campos refletindo sobre a relação delas com um dos aspectos, já investigados: o contar com imagens.

\section{Histórias e imagens - relações trazidas pelas crianças} se expressaram:

Conversando sobre como definiriam uma boa história, as crianças assim

História é [...] o que pessoa pode imaginar [...] colocando na cabeça da pessoa o que a pessoa acha para ficar mais interessante, o que a pessoa tá contando, não vendo. Eu gosto de ficar vendo as coisas [...] como ler gibi porque a pessoa vai lendo aí vai mostrando mesmo tipo um vídeo que a pessoa vai fazendo na própria cabeça imaginando como é que foi. (Narley - Escola pública)

É bom ter desenho na história porque tá mostrando o que eu vou contar... [...] Eu não gosto de ler história que não tem desenho, acho muito feia [...] Toda preta e branca. Eu tenho que desenhar depois... (Diana - Espaço cultural)

Por que a definição de uma boa história, muitas vezes, passa pela imagem, pelo desenho, pelo "ver a história"? Martin-Barbero (2002) ressalta que hoje há toda uma reestruturação das funções das práticas culturais de memória, de saber, do imaginário e da criação devido ao contexto social e cultural no qual essas crianças nascem e crescem - imersas desde cedo na "civilização da imagem".

Esse vínculo cada vez maior das crianças com a imagem, principalmente a audiovisual, que traz a ideia de que "o contar supõe o ver", como presenciam na TV, no cinema ou no vídeo parece ser algo relevante dentro do seu contexto social. A especificidade deste contato com histórias faz parte das práticas sociais das quais as crianças participam desde cedo em seu mundo. É visível hoje o quanto as crianças têm a TV, o vídeo, o computador e o video game como suportes de leitura e relação com o mundo, muitas vezes anteriores, ou mais presentes, do que sua relação com as práticas de leitura e escrita nos suportes tradicionais valorizados pela escola.

A partir das conversas com as crianças nas oficinas, e depois nas entrevistas, pude perceber que a preferência por uma ou outra história está ligada aos modos pelos quais elas se relacionam com o universo das narrativas. A preferência pelas histórias, hoje, foi ampliada relativamente a esse aumento de possibilidades de acesso, de modos de fruição e do próprio conteúdo das histórias. Um modo não substitui e anula o outro, mas diversifica a preferência das crianças. Que histórias as crianças que participaram da pesquisa preferem?

Renan: As histórias que eu mais gosto são do Pinóquio e do Saci Pererê.

Pesq.: Onde é que você conheceu essas histórias? 
Renan: A do Pinóquio eu conheci pelo filme, e o do SaciPererê foi do livro com a professora quando eu era da $1^{\circ}$ série que ela contou.

Pesq.: E tem outra história de que goste?

Renan: Batman.

Pesq.: Batman? E de onde é que você conhece o Batman?

Renan: Da Liga da Justiça, e da Liga da Justiça sem Limites.

Pesq.: Da televisão?

Renan: Da televisão e acho que também é dos jogos Titãs. (Escola pública)

Mateus: Eu gosto de histórias com muita ação, histórias medievais e também quanto entra personagens como ogro, criaturas mitológicas e também gosto de histórias de terror... Um pouco...

Pesq.: Então me dá um exemplo de algumas histórias que você gosta.

Mateus: Ghostbuster que é aquela história de terror do livro que eu trouxe... Uma de história medieval que estou lendo... dos jogos... Eu já vi Senhor dos Anéis [filme]... (Escola particular)

Gabriele: Se você quer saber a verdade (isso é meio estranho) eu adooooro a história da Bela e da Fera, da Cinderela, da Jasmin. Mas também gosto de histórias mais recentes como a coleção de livros Fala Sério, da Thalita Reboucas, dos livros Quem mexeu o meu Queijo, Uma professora muito maluquinha e muuuuuuuuitos outros. As histórias de princesas eu conheci por filmes e as outras por livros. (Bloguinho)

Luiza: Como o filme é uma história, eu gosto, por exemplo, do Crônicas de Nárnia, que tem muita fantasia e também mostra a história de Jesus.

Helena: Então é uma história real mas também... [...] fala que são os filhos de Adão, os filhos de Eva. (SESG)

Percebe-se que as crianças gostam tanto das histórias da cultura popular, como o Saci-Pererê, e da tradição oral como os contos de fada (Pinóquio, Cinderela, A Bela e a Fera, Chapeuzinho...), quanto do Batman da TV, do filme O Senhor dos Anéis, das histórias de ação, de terror, medievais que aparecem nos livros, nos filmes, nos jogos. O gosto pelas histórias tradicionais mescla-se com o gosto pelas histórias presentes nas mídias. As crianças mostram que conhecem e circulam por diferentes histórias em diferentes suportes. Parece haver uma certa complementaridade nesse convívio entre suportes/formas de entrar em contato com as histórias. O livro remete aos jogos, aos filmes e assim por diante e vice-versa. São as "trocas alternadas" de que nos falou uma criança em pesquisa anterior. ${ }^{3}$ 
Dentro desse contexto percebe-se como livros e filmes aparecem com maior incidência na fala da maioria das crianças, sendo os suportes que preferem e os quais mais se utilizam para ter acesso às histórias. Como Laura comenta: "acho que os livros e filmes são muito parecidos..."

Luiza: [...] eu gosto muito de ver filme [...] Mas pelo livro também é bom porque tem várias histórias, várias formas, assim... histórias reais, histórias inventadas. No filme é mais história inventada, não tem muita variação [...] (SESC)

Pesq.: Agora, quais são as histórias, assim, se eu disser pra você, "Ah, me diz uma história que você gosta muito, e onde é que você conheceu essa história?”.

Renan: Eu gostei do, da história do Picote que conheci na biblioteca daqui do colégio. Foi a primeira história que eu li.

Julie: Eu gosto mais da Branca de Neve... porque tem suspense, tem, tipo, muita crueldade, tem amizade, tem alegria.

Pesq.: E onde é que você conheceu?

Julie: Conheci no filme, eu tenho um filme desse, mas meu irmão foi jogar no chão [o DVD], aí arranhou e estragou. (Escola pública)

Pesq.: Você falou que vê mais histórias em livros, essa é a maneira que você mais gosta, que você prefere ou tem outras maneiras de entrar em contato com histórias que você prefira?

Mateus: Bom... Em filmes. No próprio video game mesmo, e numa revista. (Escola particular)

As falas das crianças apontam que pensam nas histórias principalmente nos livros e nos filmes, dois locais de acesso e fruição vivido por elas. Eco (apud AGUIAR, 2003) explica a complementaridade entre livro e cinema ao dizer que narrativa literária e filme cinematográfico são artes de ação, pois partem de um mesmo processo de fabulação que os alicerça. Por vezes, os filmes também remetem a revistas e video games como transparece na fala de Mateus. Tal complementaridade entre os diferentes suportes relaciona-se estreitamente com a noção de convergência midiática. A convergência é, segundo Jenks (2008), um conceito antigo assumindo novos significados. Com a revolução digital se presumia que as novas mídias substituiriam as anteriores. A convergência mostra que há uma transformação no modo como as histórias passam a circular na cultura. Jenks chama de cultura da convergência, a qual podemos relacionar à cultura que Canclini (2003) nomeia por híbrida, uma cultura que se mistura no seu modo de ser criada, ser apropriada e em seu modo de circular, ser compartilhada em meio às práticas culturais vividas. 


\section{O livro - lugar que tem mais histórias...}

Um aspecto que chamou a atenção nas falas das crianças, que apontam conhecer histórias em vários locais, foi o reconhecimento do livro como o primeiro lugar de acesso a histórias. Essa constatação surgiu em todos os campos pesquisados de forma unânime. Mesmo levando diferentes materiais com histórias, as falas das crianças reforçavam a ideia de que o lugar que tem mais histórias é o livro. Assim, parece que o livro ainda é reconhecido como o local "por direito" das histórias, talvez por ser um dos locais que as crianças sabem que é legítimo nessa função.

Israel: Lugar que tem mais história é a biblioteca.

Pesq.: Por que você acha que é na biblioteca?

Israel: Porque na biblioteca tem um monte de livros, você pode ler os livros, você pode pegar, ler e ficar sabendo das coisas. (Escola pública)

Pesq.: Em que lugar você conhece mais histórias?

Gabriela: Na biblioteca.

Pesq.: Na biblioteca? Por que você acha que tem mais histórias na biblioteca?

Gabriela: Porque foi o único lugar que eu já fui e vi um monte de livros. (Escola particular)

A ideia da biblioteca como local de mais acesso às histórias aparece associada à ideia de que as histórias, por direito, estão nos livros. Não deve ser à toa que a frase de Lobato, em carta a Frederico Rangel em 1926, ainda permanece atual quando dizia "Ainda acabo fazendo livros onde as nossas crianças possam morar." No entanto, depois dos livros ou da biblioteca, por vezes, reconhecem a existência de histórias em outros suportes e em outros locais como é o caso das situações a seguir:

Pesq.: Agora, tem outro lugar além da biblioteca, que você ache histórias?

Israel: Tem! É na Internet, nos sites do Pica-pau. (Escola pública)

Pesq.: E fora o livro, tem outros lugares que têm histórias?

Arthur: Na televisão.

Pesq.: E fora a televisão tem outro lugar?

Arthur: No computador, no computador eu faço histórias. (Escola particular)

Elisabetta: Tem histórias em casa, de noite, e no colégio e quando vou em livrarias. No colégio é na biblioteca e na sala de aula ou até no recreio, quando minhas amigas me contam alguma coisa que aconteceu de legal. Eu estudo em turno integral, então acontece muita coisa lá. Em casa eu vejo histórias na televisão, quando a minha mãe me conta e no computador. (Bloguinho) 
Assim, a televisão, o computador, os jogos, os filmes aparecem também mesmo que eles falem dos livros primeiro ou reafirmem que, diante de todos esses lugares, é o livro o lugar que mais tem histórias.

Júlia: Eu leio mais nos livros com certeza... nos jogos, normalmente não [tem história], mas raramente aparece um ou outro que têm, por exemplo nos de vestir, têm alguns que aparece uma menininha que você veste e depois você tem que levá-la para encontrar-se com o príncipe, isso não deixa de ser uma história... (Bloguinho)

Helena: Eu, eu acho que [as histórias] estão mais nos livros porque normalmente são os livros que contam histórias do passado, fazem a gente aprender pra gente poder criar uma nova história.

Pesq.: Entendo.

Helena: E eu acho que normalmente são os livros mesmo porque eles falam de tudo o que a gente tem que saber, ou a Internet, coisas que falem sobre o passado. Não é como a televisão, que normalmente só fala sobre o futuro ou sobre o que aconteceu hoje. Tem que ser uma coisa que fale do passado, do futuro e do presente. (SESC)

Talvez possamos dizer que, no processo de formação dessas crianças, é o livro o suporte mais conhecido e mais valorizado. O livro ajuda a "ficar sabendo das coisas", é "uma boa fonte de histórias", além de serem eles que "contam as histórias do passado". É por tudo isso que os livros os ajudam a "aprender para poder criar uma nova história", como nos dizem as crianças da pesquisa.

Diante dos depoimentos, não é demais supor que o livro não é mesmo um "mero objeto", mas traz aspectos formadores da maneira como as crianças concebem a sua relação com as histórias. Interessante perceber também que a relação que Helena estabelece em sua fala entre histórias e passado associa o livro a um portador das histórias do passado e a TV como algo que fala do presente e do futuro. Uma história, completa ela, tem que ser "uma coisa que fala do passado, do futuro e do presente". Implicitamente essa menina fala da história nesse tempo longo, estendido, numa relação de continuidade da história, uma relação associada ao contar de que fala Benjamin (1994). Para ela, o livro carrega a dimensão benjaminiana de história associada à rememoração pela retomada salvadora do passado pela palavra, espaço no qual podemos ler as histórias que a humanidade conta como fluxo constitutivo da memória e, portanto, de sua identidade.

Martín-Barbero (2002) argumenta que há hoje toda uma reestruturação das funções e das práticas culturais da memória, do saber, do imaginário e da criação e, se hoje já não se escreve e nem se lê como antes, é também porque não se pode ver e nem representar como antes. Tal autor afirma que o livro continuará sendo a chave da primeira alfabetização - a que abre o mundo da escrita - mas que, em vez de "encerrar-se" a alfabetização apenas sobre a cultura letrada, esta será a base para a segunda alfabetização, aquela que se abre às múltiplas escritas que 
hoje conformam o mundo do audiovisual e do texto eletrônico. A mudança nos protocolos e processos de leitura de que fala Sarlo (apud MARTÍN-BARBERO, 2002) não significa a substituição de um modo de ler por outro, mas sim a complexa articulação de uns e outros, da recíproca inserção de uns em outros, entre livros, quadrinhos, vídeos e hipertextos.

A fala de uma das crianças leva à reflexão sobre os modos de ser leitor em que o convívio com outros suportes de leitura modifica a constituição da relação com o livro na contemporaneidade, pois já aponta mudanças nas práticas culturais pelas relações que estabelecem com as imagens e outros suportes não lineares de leitura:

Luiza: Eu tenho um monte de livro, tenho livro grosso, livro fino, cada dia eu leio um pouco de cada livro pra não ficar enjoativo ler um livro só. (SESC)

\section{Histórias "da mochila": contando histórias com imagens de livros que não leram}

Algumas crianças tinham uma tal desenvoltura no lidar com as histórias que acabavam contando histórias dos livros que pegavam ali naquele momento, no local em que estava sendo feita a oficina, e as contavam às demais pelas imagens mesmo sem as terem lido anteriormente. Outras pegavam as histórias "da mochila" e improvisavam uma contação ou relato.

\section{Situação 1}

Maria Clara (fala muito baixinho): A minha é de um homem que se apaixona... e depois eu não sei... não li...

Pesq.: Mas por que vocês trouxeram uma história de um livro que vocês nem leram?

Maria Clara: É que a gente não tinha trazido e a gente tinha esse na mochila...

Situação 2

lago: O bosque selvagem. Era uma vez um bosque... (Iago ia lendo devagar e os colegas se distraiam pela lentidão da leitura de iniciante) e saíram... a procura de... sementes para...

Pesq: Iago, como a história é grande, conta e mostra para nós como é a história. Não precisa ler tudo senão não dá tempo dos outros contarem a deles para todo mundo, OK?

Clara: Ele não sabe... Ele não leu...

Pesq.: É a primeira vez que você está lendo essa história? O que você achou dessa história? É legal?

lago: É sim!! Ela tem muita página!

Assim Iago ia mostrando as figuras e apontando o que estava acontecendo, lendo de vez em quando uma parte da história... 
A turma toda ficou interessada, um ou outro falava junto mas a maioria acompanhava a história contada...

lago: Olha, todos os animais, gente!

(Situações do caderno de campo - Escola particular)

Em mesa de debate na Festa Literária de Parati de 2008, o escritor Pierre Bayard discute o seu livro que fala sobre "Como falar dos livros que não lemos?" em que mostra que, muitas vezes, pode-se falar de um livro não lido. Umberto Eco (2007), em resenha escrita sobre o livro do referido autor, aponta que Bayard percebe que conhecemos o conteúdo de alguns desses livros porque já lemos outros livros que falavam deles ou se moviam dentro da mesma ordem de ideias. Parece que é o que as crianças fazem ao brincar de contar aos outros livros não lidos por meio do conhecimento das histórias dos que já leram. Isso porque Bayard aponta que:

Não está tão interessado em que as pessoas leiam os livros alheios, mas antes no fato de que cada leitura (ou não-leitura) tenha de ter um aspecto criativo e que (utilizando palavras simples) em um livro o leitor tenha de colocar, antes de tudo, farinha de seu saco. A ponto de auspiciar uma escola em que - já que falar de livros não lidos é uma maneira para conhecer a si próprios - os estudantes "inventem" os livros que não deverão ler. (apud ECO, 2007)

O fato de inventarem ou contarem livros não lidos foi algo que não ocorreu em todos os grupos, mas apenas num deles, justamente os que tinham muito contato e familiaridade com as histórias. Como Bayard aponta, até para inventar ou falar sem ler é preciso conhecer bem o universo dos livros.

\section{Histórias que estão "só na cabeça"}

Pensando em como inventar livros que não deverão ler, como nos diz Bayard (apud ECO, 2007), várias eram, no contexto de um dos grupos, as histórias que apareceram, as quais as crianças diziam estar "só na cabeça", justificativa para poder contar a história sem ter trazido o livro, revista, vídeo ou qualquer suporte de existência da mesma.

Pesq.: Eu quero saber primeiro essas histórias que vocês trouxeram..

Clara: Eu quero falar a minha que está só na cabeça...

Gabriela: Ah, por favor!! Eu também!! Eu quero contar um pedacinho... Só um pedacinho pequeninho...

Pesq.: Bom, vocês duas, a história que vocês trouxeram que está na cabeça, é de onde? É da escola ou é de fora da escola?

Clara: Não, é da minha casa...

Gabriela: É da minha casa... (Escola particular) 
As histórias que "estão só na cabeça" são histórias com as quais tiveram contato em casa, foram vistas, lidas ou contadas pelos pais e elas passam adiante o que lhes foi contado. A família configura-se aí como um espaço importante de motivação das crianças no contato e acesso às histórias. Gilka Girardello (on-line) comenta que, muitas vezes, ao contarmos histórias para as crianças elas pedem para contar "uma de livro" ou "uma de cabeça". A autora comenta que, desde cedo, as crianças percebem que certas histórias funcionam melhor no improviso, quando se pode mergulhar na fantasia. "E que em outras, ao contrário, o prazer depende da cadência hipnótica da leitura, do ritmo preciso das palavras do autor, nessa experiência forte que é o primeiro encontro com o prazer do texto.” (p. 1)

Um aspecto interessante também é a marca que as que "estão só na cabeça" parecem trazer. São histórias significativas para quem conta, foram contadas na maioria das vezes por pessoas queridas da família, trazem dentro delas outras histórias de como foram ouvidas, lidas, adquiridas e contadas. $\mathrm{O}$ "estar na cabeça" mostra que a história já faz parte do repertório da vida dessa criança, trazendo uma dimensão de afetividade que a torna ainda mais significativa para ser passada adiante. Para contar essa história, o livro ou o suporte a partir da qual teve acesso a ela, já não é mais necessário pois o "estar só na cabeça" mostra que a história, como lembram e contam, não é mais a que está lá registrada, mas é outra, como ocorre com Lucia no conto de Galeano:

Muito caminhou Lucia, e ao longo de seu caminhar ia sempre acompanhada pelos ecos daquelas vozes distantes que ela tinha escutado, com seus olhos, na infância. Lucia não tornou a ler aquele livro. Não o reconheceria mais. O livro cresceu tanto dentro dela que agora é outro, agora é dela. (GALEANO, 2008, p. 20)

\section{Livros que conheço "só de ver"}

Ao longo dos encontros com as crianças nas oficinas, um aspecto chamou a atenção: a forma como escolhiam as histórias que queriam trazer, que queriam ler, os filmes que queriam contar. Foi perceptível a escolha delas, em suas primeiras impressões, como associadas às imagens dos produtos com histórias. Assim como percebi que elas contam histórias pelas imagens, mesmo sem as terem lido, trago as referências que as crianças fazem ao visual associado às histórias, mais particularmente em relação aos livros e sua visualidade antes mesmo de entrarem em contato direto com eles pela leitura do escrito, configurando uma forma de "ver o livro". Estarão essas crianças já antecipando uma nova forma de ler pelas imagens?

Esta ideia das crianças de conhecer um livro "só de ver" parece trazer implícito o leitor das imagens da cidade, dos seus signos e luzes: leitor movente de que nos fala Santaella (2004). O fato de verem tais livros com frequência configura um tipo de conhecimento. 
Pesq.: Vamos lá? Quem mais trouxe... Mateus fala o seu... A sua história fala de que?

Mateus: É de dois irmãos que eles estavam de férias de verão e... a mãe deles mandou eles para um acampamento com o nome do espírito da lua e lá eles tem um monte de brincadeira estranha, começa todo mundo a se machucar... Essas coisas...

Pesq.: Qual é o nome do livro? È Ghostbuster...

Frederico: Não, esse é o nome da série... O nome do livro é embaixo...

Julia: Acampamento fantasma...

Todos: O que!!! Você não sabe ver...

Pesq.: Todo mundo lê esse livro?

Julia: Não..

Pesq.: Como vocês sabem que o nome do livro é embaixo?

Bernardo: Eu conheço do anúncio da TV, da propaganda...

Pesq.: Mas você nunca leu nenhum desses?

Bernardo: Não... Conheço só de ver... (Escola particular)

O "conhecer só de ver" parece demonstrar um acesso contínuo a esses livros, pois de tanto ver acabam conhecendo-o. Essa presença da visão tanto na escolha do que é mais legal ler quanto no "reconhecimento" de detalhes de livros que não leram demonstra mesmo que podem falar dos livros sem os terem lido. Algumas informações básicas a respeito da série, dos temas, entre outras podem ser abordadas por eles numa conversa, mesmo que nunca tenham lido esta coleção de livros.

O conhecimento do livro pela imagem, no entanto, traz outras dimensões não propriamente visuais como o lugar do título, o nome da série, que incluem referências de outra ordem para o leitor. Conhecer "só de ver" configura um tipo de conhecimento que as crianças vão adquirindo no seu cotidiano, pelo contato com as imagens tanto de livros quanto de outros meios que provavelmente também "conhecem só de ver".

Mitchell (1995 apud SARDELICH), em uma de suas primeiras publicações já advertira que, apesar da noção "visual" constituir uma dimensão diferente da linguagem verbal, isso não implica que a cultura visual não mantenha relação com as outras linguagens e/ou sentidos. A noção de cultura visual é nova precisamente por centrar-se no visual como um lugar no qual se criam e se discutem significados. A capa dos livros que as crianças "conhecem de ver" e que os ajuda nas escolhas do que é mais interessante ler, relaciona-se com esta cultura visual na qual as crianças se encontram imersas. 


\section{Considerações finais}

As considerações trazidas nesse artigo referem-se a um aspecto da pesquisa que perpassou os campos estudados e que me chamou a atenção: o vínculo da criança com o contar pela imagem. $\mathrm{Na}$ pesquisa em questão surgiram vários aspectos desse "contar pela imagem" e ressaltou-se, que mesmo vivendo num mundo amplamente tecnológico, as crianças reconhecem o livro como local das histórias associando-o, no entanto, às imagens já amplamente presentes nas tecnologias da atualidade. Percebe-se como as imagens são constituidoras dos modos das crianças contarem suas histórias e que estas reconhecem-nas como devem ser contadas ou escolhidas para serem passadas adiante. O contar pela imagem foi algo recorrente quando falam que a história é melhor contada quando também "é vista", quando escolhem os livros com imagens e pelas imagens. Percebe-se também que, assim como os livros com suas imagens, os quadrinhos, os filmes e todos os locais que contam histórias se tornam mais legítimos do ponto de vista delas se trazem imagens.

Os livros "que não leram", as histórias que "estão só na cabeça" e as que "conhecem só de ver" configuram um modo de relação com as histórias mediado pelos modos de relação com a imagem. Com a imagem posso ter uma relação diferente da estabelecida com a oralidade ou com a escrita. Benjamin (1994) já nos faz pensar sobre isso quando aponta que a recepção através da distração, que se observa crescentemente em todos os domínios da arte, constitui o sintoma de transformações profundas nas estruturas perceptivas. Tal recepção, segundo ele, tem no cinema seu cenário privilegiado (p. 194). Pode-se pensar que essa relação que fazem entre livros e filmes não é fortuita e aponta a forte presença da imagem no ponto de vista delas fazendo até mesmo parte de sua relação com os livros.

Nesse sentido as crianças relacionam-se com as narrativas de modo híbrido. As hibridações (CANCLINI, 2003) já fazem parte do cotidiano delas quando falam, indistintamente, sobre contos lidos, narrados e vistos. Percebese que as narrativas, como mostraram as crianças, estão na cabeça, nos livros, na TV, nos filmes, nos videogames, embora perceba-se que nem todas as narrativas tenham a mesma legitimidade do ponto de vista delas. Destaca-se que as histórias precisam das imagens para serem escolhidas, lembradas e contadas pelas crianças, demonstrando a força que a imagem adquire nesse contar das crianças.

A criança que nasce neste contexto de múltiplas narrativas já "migra" e "mistura" escrita e imagem, assim como mistura as histórias que entra em contato em diferentes suportes, desde seus primeiros contatos com esse mundo. Já vivenciam e realizam hibridações entre as histórias e entre os modos de criar e fruir as mesmas em seus diferentes espaços de convivência. Nesse sentido as crianças constituem-se, inegavelmentente, como protagonistas de novas formas de ler e interpretar o vivido nessa relação híbrida entre histórias e imagens no cotidiano. 
Se a imaginação e a criatividade entendidas pela escola estiverem dispostas apenas nos formatos conhecidos pelos adultos em sua infância (apenas como modelos do que era ser criativo na infância deles) não reconhecendo como imaginação ou criatividade nada que não traga seus parâmetros na criação, pode-se fechar às crianças as possibilidades de criarem diante desse novo contexto. Manuel Castells (apud MARTIN-BARBERO, 2002) me ajuda a entender que o novo modo de produzir e contar se acha inextricavelmente unido a um novo modo de comunicar, convertendo o conhecimento em uma força produtiva direta: "não foi o tipo das atividades das quais participam a humanidade que mudou, o que mudou foi sua capacidade tecnológica de usar como força produtiva aquilo que distingue a espécie humana como raridade biológica: sua capacidade para processar símbolos". Com isso, Castells mostra que a criatividade das sociedades ocidentais (muito bem expressa pelas crianças na pesquisa) passa hoje, de modo significativo, pela tecnologia que sempre nos traz a imagem como forma de contar.

\section{Referências}

ARIÈS, P. História social da criança e da família. Rio de Janeiro: Guanabara,1983.

BAYARD, P. Como falar dos livros que não lemos? Rio de Janeiro: Objetiva, 2007.

BENJAMIN, W. O narrador: considerações sobre a obra de Nicolai Leskov. In: Obras Escolhidas I: magia e técnica, arte e política. São Paulo: Brasiliense, 1994.

- A obra de arte na época de sua reprodutibilidade técnica. In: Obras Escolhidas I: magia e técnica, arte e política. São Paulo: Brasiliense, 1985

CANCLINI, N. Culturas Híbridas: estratégias para entrar e sair da modernidade. São Paulo, EDUSP, 2003.

CASTRO, L. R.; BESSET, V. L Pesquisa-intervenção na infância e juventude. Rio de Janeiro: NAU/FAPERJ, 2008.

CORSARO, W. Sociologia da Infância. Porto Alegre; Artmed, 2011.

ECO, U. Os livros que não lemos. Revista Entre Livros, outubro de 2007. Disponível em: <www.blogdogaleno.com.br> Acesso em: jul. 2008.

FERNANDES, A. H. Infância e cultura: o que narram as crianças na contemporaneidade? Brasil, Tese (Doutorado em Educação), Programa de Pósgraduação em Educação, Universidade do Estado do Rio de Janeiro, Rio de Janeiro, 2009.

FERNANDES, A. H. As mediações nas produções de sentido das crianças sobre os desenhos animados. Brasil, Dissertação (Mestrado em Educação). Programa de Pós-graduação em Educação, Pontifícia Universidade Católica do Rio de Janeiro. Rio de Janeiro, 2003.

GIRARDELlO, G. Tevê, Narração Oral de Histórias e o Imaginário Infantil. Florianópolis, NET, Disponível em: <http://www.ilea.ufrgs.br/ppgcom/ professores/nucleos/conesul/tev_crian/tevcri_tex09.htm> Acesso em: jul. 2005. 
GALEANO, E. O livro dos abraços. Porto Alegre: L\&PM, 2008.

HOBSBAWN, E. J. A era dos extremos: o breve século XX: 1914-1991. São Paulo: Companhia das Letras, 1995.

JENKS, H. Cultura da Convergência. São Paulo: Aleph, 2008.

MARTÍN-BARBERO, J. La educación desde la comunicación. Buenos Aires: Grupo Editorial Norma, 2002.

PRATES, M. E a tela invade a página (laços entre literatura e cinema em Hotel atlântico, de joão Gilberto Noll). IN: VALVERDE, M. As formas do sentido: estudos em estética da comunicação. Rio de Janeiro: DP\& A, 2003.

PERROTTI, E. A criança e a produção cultural (apontamentos sobre o lugar da criança na cultura) In: ZILBERMAN, R. (Org.). A produção cultural para a criança. Porto Alegre, Mercado Aberto, 1990.

SANTAELLA, L. Navegar no ciberespaço: o perfil cognitivo do leitor imersivo. São Paulo: Paullus, 2004.

SARDELICH, M. E. Leitura de imagens e cultura visual: desenredando conceitos para a prática educativa. Educar, Curitiba, n. 27, p. 203-219, 2006. Editora UFPR. Disponível em: <http://www.scielo.br/pdf/cp/v36n128/v36n128a09.pdf> Acesso em: jul. 2009.

\section{Notas}

${ }^{1}$ Quando falo sobre o desenvolver pesquisas "com” as crianças trata-se de explicitar uma orientação metodológica, ou seja, é o modo como se trabalha com uma investigação que entende as crianças como coautoras na produção da pesquisa, característica que não é contemplada nas pesquisas "sobre" as crianças. Como exemplo desse tipo de orientação metodológica temos os estudos de Corsaro (2011) na ótica da sociologia da infância e até mesmo os estudos de pesquisa-intervenção de Castro (2008). Nessa concepção, a criança participa da condução da pesquisa, pois suas contribuições podem interferir na continuidade ou na mudança de rumo da investigação. É uma perspectiva diferente no que se refere à condução da pesquisa sobre as crianças em que a atuação das crianças é restrita.

${ }^{2} \mathrm{O}$ bloguinho pode ser acessado pelo site do Globo: <http://oglobo.globo.com/blogs/bloguinho/>

${ }^{3}$ Refere-se à pesquisa "As mediações nas produções de sentido das crianças sobre os desenhos animados" finalizada na PUC-Rio em 2003. 
* Adriana Hoffmann Fernandes - Professora Doutora, pesquisadora na área de Educação e mídias, da Universidade Federal do Estado do Rio de Janeiro. Rio de Janeiro, Rio de Janeiro, Brasil.

\section{Correspondência}

Adriana Hoffmann Fernandes - Universidade Federal do Estado do Rio de Janeiro, Departamento de Didática, Rio de Janeiro, Brasil.

Av. Pauster, 458, CEP: 22290-240, Urca, Rio de Janeiro.

E-mail: hoffadri@yahoo.com.br

Recebido em 08 de junho de 2012

Aprovado em 06 de fevereiro de 2013 
